\begin{tabular}{c} 
Volume and Issues Obtainable at Center for Sustainability Research and Consultancy \\
Journal of Business and Social Review in Emerging Economies \\
ISSN: 2519-089X (E): 2519-0326 \\
Volume 6: No. 1, March 2020 \\
CSRᄃ \\
Journal homepage: www.publishing.globalcsrc.org/jbsee \\
\hline
\end{tabular}

\title{
Exploring Difference in Gender Perceptions towards Teacher's Motivational Behaviour in English Language Classroom
}

\author{
${ }^{1}$ Zulfiqar Ali, ${ }^{2}$ Farzana Masroor, ${ }^{3}$ Tariq Khan \\ ${ }^{1}$ Assistant Professor, Department of English, City University of Science and Information Technology, \\ Pakistan \\ ${ }^{2}$ Assistant Professor, Department of English, Air University, Pakistan \\ ${ }^{3}$ Assistant Professor, Department of English, University of Malakand, Pakistan. \\ tariqkhan1975@gmail.com
}

\begin{tabular}{|c|c|}
\hline ARTICLE DETAILS & BSTRA \\
\hline History & \multirow{7}{*}{$\begin{array}{l}\text { The role of a teacher is crucial for language learning specifically in } \\
\text { English language classrooms. An important variable in this regard is } \\
\text { the gender of students. This study investigates the impact of gender } \\
\text { on language learning motivations of students studying at the } \\
\text { undergraduate level in the City University of Science and IT and } \\
\text { Institute of Management Sciences, Peshawar. Questionnaire data } \\
\text { were collected from } 175 \text { students. The variables of the study include } \\
\text { gender and its relationship with language attitudes and motivation. } \\
\text { The results revealed that there exists the relationship between } \\
\text { gender differences in variables under consideration. Female } \\
\text { students had more expectations as compared to their male fellows. } \\
\text { The study has useful pedagogical implications. }\end{array}$} \\
\hline 020 & \\
\hline & \\
\hline & \\
\hline$n s$, & \\
\hline & \\
\hline LL Class & \\
\hline
\end{tabular}

\section{OPEN ACCESS}

(C) 2020 The authors, under a Creative Commons AttributionNonCommercial 4.0

Corresponding author's email address: tariqkhan1975@ gmail.com

Recommended citation: Ali, Z., Masroor, F. \& Khan, T.(2020). Exploring Difference in Gender Perceptions towards Teacher's Motivational Behaviour in English Language Classroom. Journal of Business and Social Review in Emerging Economies, 6(1), 331-338

DOI: $10.26710 /$ jbsee.v6i1.1068

\section{Introduction}

The need for adequate oral English language communicative competence among learners in English Language Teaching classrooms is well established. However, the attainment of such competence is a matter of great concern in educational settings of Pakistan. Despite the realization for improving the competency, English language learners fail to achieve this goal even after the successful completion of their basic education. Several studies in Pakistani context have raised their concerns regarding the quality of teaching practices with specific reference to Khyber Pakhtunkhwa (KPK) (Ali et al., 2016; Nawab, 2012). One of the hindrances observed by the administration of Higher Education (HE) institutions in KPK to improve learners' proficiency is their lack of motivation in learning the English language. The attitude and motivation towards the target language are among the most crucial factors in learning a 
language.

In the area of educational psychology, developments in motivation and its dynamics have gained increased empirical attention in recent years (Murphy \& Alexander, 2000; Pintrich, 2000). The term motivation is explained by Dornyei (2001) as among the most foundational aspects of human cognition and fundamental for the outcomes of a language learning activity. The motivation is the impetus to do something, which is a form of inspiration and is translated in the form of energy to make certain things happen (Ryan \& Deci, 2000). Attitude is closely linked to motivation as both considered as crucial in achieving certain goals. Since attitude and motivation are behavioural traits, they can be linked to the external environmental conditions as well. In this regard, the role of the teacher has been emphasized by several studies to positively or negatively impact the learning process. Therefore, motivation plays a crucial role in success in language learning.

Maslow (1970) has identified five basic motivational needs as psychological needs, safety needs, love and belonging needs, esteem needs and self-actualisation. It is a challenge for English language teachers to motivate their students. A good teacher should be able to enhance both the intrinsic and extrinsic motivation levels of its students in a language classroom. The intrinsic motivation usually comes from within where one tries to achieve the intended goals as an act of self-satisfaction (Ryan, et al., 2000). The role of the teacher is crucial as inculcating this life-long skill can be carried out by empowering the learner. Extrinsic motivation is mostly driven by some external rewards and the ultimate goal of gaining some job, status or monetary benefit can lead to achieving success in a language learning classroom (Deci and Ryan, 2000).

The teachers of English usually manage a classroom with the adoption of varying teaching techniques quite effectively. Yet they struggle to handle motivation and attitude problems of students since their expected student achievements are not easily met (see Brophy, 1987, Dornyei, 2001, Dornyei, Ushioda, 2011). A similar situation was observed by Ericksen (1978:3) in the late 70s when he states that "effective learning in the classroom depends on the teacher's ability ... to maintain the interest that brought students to the course in the first place."

In Pakistan, this problem requires the attention of research since fewer studies, particularly in Khyber Pakhtunkhwa, have focused on the crucial role played by attitude and motivation of learners for obtaining proficiency at the English language. Some progress has taken place in this regards at various levels. The administrations belonging to different educational institutions in Khyber Pakhtunkhwa have expressed their desire to facilitate the learning process. This includes seriousness towards English language teaching by introducing training programs for the teachers to improve teachers' communicative competence and language proficiency. The learners' response towards language learning is still problematic and they fail to come up to the desired expectations.

\section{Literature Review}

The motivational impact is understood in terms of linear cause-effect relationships (Dornyei, 2001). The driving force of motivation is not seen as a static attribute but rather as a dynamic factor that displays continuous fluctuation (Dornyei, 2005).

Several studies have linked the motivation with the teachers' role in the language classroom. In Pakistani context in Sindh, Wadho et al. (2016) attempted to analyse the role of both the teachers and parent in language learning. The study emphasized the role of parents, teachers and their positive feedback as crucial factors for attaining learners' proficiency. In a study carried out in Quetta, Ali and Pathan (2017) revealed a closer link between learning a second language and environmental factors. The negative impact on learning was observed concerning the course contents, teaching methods and materials, lack of interest and teachers' negative behaviour. The impact of learners' attitude and motivation towards English language learning was also studied by Pathan (2012) who revealed a direct link of confidence and self- 
esteem with their learning needs. Similarly, Mansoor (2016) recommended studying attitude and motivation of learners in second language classrooms.

The focus of research on language learning also incorporated the role of gender and became an integral part of mainstream SLA research. The variable of gender has intrigued researchers working in the domains of both the psycho- and sociolinguistics. Among the individual differences in learners' styles, gender became a crucial aspect to study motivation. There is, nevertheless, quite a good deal of studies on attitudinal/motivational variations across genders regarding the specific socio-cultural and/or sociopolitical context of EFL learning (McElhinny, 1993). Several studies have shown that there is a link between gender and attitude and motivation which have provided the evidence that gender is one the most important variables that have a direct impact on learners' attitude and motivation towards language learning.

Gender roles are specifically patterned attitudes, behaviours, and expectations that are interpreted based on being male or female. The differences are interpreted not only based on their physiological differences but their social roles and psychological dispositions. There is a general pattern that can be observed in the way girls and boys behave at school and in classrooms, although there is a room for a few exceptions. The differences in the physical, social and psychological dispositions may also emerge from the way they are influenced by their parents, teachers, peers and media. The role of a teacher in the classroom cannot be undermined as it directly affects their responses and choices made in the learning situations in the classroom.

The physical differences among the two genders mostly are evident in the ways boys are comparatively more restless and physically aggressive than the females when in frustration (Espelage \& Swearer, 2004). This is the average trend and we cannot ignore the individual differences that may result in a less active boy and a restless girl. The role of the teacher as a mentor is specifically crucial in such a situation where giving extra attention to such students by a teacher may be witnessed and create disproportionate attention to a few students. The agility among boys also results in their higher social mobility and active involvement in competitive games and sports (Maccoby, 2002). The general trend in girls is observed as having a small social circle with a group of a few intimate peers sharing a close bonding and sharing of inner feelings. These general differences may also be observed in classrooms where boys can be more interactive in the classroom environment. Their involvement in the classroom may also be uninvited and may result in creating some bifurcation where they tend to ignore or undermine girls' contributions to the classroom learning situations. Although some differences are reported in the cognitive abilities of the two genders as well, where boys are found to be more proficient in mathematics and girls in arts and literature, these differences are getting minimised through more empirical studies.

There is a general trend that girls appear to be more motivated in the classroom to perform well. The studies also show that females' attitude and motivation towards language learning is stronger than male ones (Kissau, 2006; Öztürk \& Gürbüz, 2013; Ahåt, 2013). It is also worth mentioning that in previous studies, female learners were found with higher motivation demanding much from their teachers to meet their expectations and the satisfaction level of the female learners was found below as compared to male learners. For example, the study conducted by Dweck \& Gilliard (1975) negated the perception of the earlier studies in which male learners were shown with higher expectation than females; however, the female learners were found with stronger educational expectations than the male ones. In similar research conducted by Dornyei \& Csizér in Hungary; the findings from 14- year olds Hungarian students revealed that male students are less motivated to learn a second language than female students. Their findings demonstrated that girls display superior language attitudes than boys. Their findings support previous research reported from a variety of literature where girls showed better learning performance than male in language learning. Dornyei \& Csizer found that learning a second language is perceived by the boys as a "girly" subject (2005). This shift may be due to female standing on higher social status today over the last few decades. 
The role of the teacher in such situations is crucial. The teacher is expected to foster learning skills in the students and has a major motivational role (Dornyei, 1994; Williams and Burden, 1997; Noels et al., 1999). The traditional view of teaching placed the teacher on a high pedestal with a higher authoritative role (Wright, 1987). However, the actual classroom scenario may demand a different role from the teacher. The effective learning may involve interactive teaching Moyles et al. (2003) where the teacher may create an atmosphere for the healthy discussion and feedback mechanism. The modern concept of teaching focuses on the role of a teacher as a facilitator and which is a much learner-centred approach (Nunan, 1995). McDonough and Shaw (2003) encourage the role of a teacher as a prompter that aids learning through the prompts and helps increase the motivation for learning. As a resourceful organiser, the teacher selects the relevant material and manages the teaching process by ensuring the learning of the required skills in the students.

The present study has included gender differences related to attitude and motivation towards language learning to examine gender differences concerning teachers' motivational behaviour to provide more recent evidence.

\section{Methodology}

The study is conducted in two high profile universities of Khyber Pakhtunkhwa selected from public and private sectors each-City University of Science and Information Technology, Peshawar (CUSIT); and Institute of Management Sciences, Peshawar (IMS). The easy access to the institutions and support of administration helped towards achieving the goals of data collection. The research design is crucial in achieving research objectives. This is a descriptive research of the survey type. The attitude and motivation of learners are taken as dependent variables whereas gender is taken as an independent variable. The population comprised of students $(\mathrm{N}=175)$ studying in undergraduate programs including management, computer sciences, engineering and education. A self-administered questionnaire was used for this study as it is the common practice used in the research of second language motivation. The questionnaire format was close-ended. 7 Likert scale was used and data was then analysed by using the technique of Statistic Package for Social Sciences (SPSS). A survey questionnaire is a well-reputed tool for the study of attitude and motivation. According to Dornyei (2010), it is a versatile and easy way to gather a large amount of data from respondents in a short time. It has been authenticated to research beliefs, motivation, attitude, concepts, and social and personal traits (Kerlinger, 1986). Several ethical considerations were taken into account for the conduct of study such as the consent of participants. Their anonymity, confidentiality and privacy was ensured.

\section{Results}

The 23 items on the questionnaire are provided in Table 1 below. The items reflect the learners' attitude and motivation towards English language learning concerning the teacher's role in a language classroom. The items were structured to measure the extent to which a teacher shows enthusiasm in class, makes learning an enjoyable experience, makes efforts in improving learners' language ability, links learning experience with the extrinsic and intrinsic motivation, imparts confidence in learners, related learning activities to everyday life, appreciates learners, avoids embarrassing students, avoids negative criticism and builds friendly atmosphere in the classroom.

Table 1 Questionnaire from Learners (Male and Female)

\begin{tabular}{|l|l|l|l|}
\hline Items & & $\begin{array}{l}\text { Female/M } \\
\text { ean }\end{array}$ & $\begin{array}{l}\text { Male/Me } \\
\text { an }\end{array}$ \\
\hline 1 & Teacher showing enthusiasm while teaching & 5.1600 & 4.9646 \\
\hline 2 & Enjoying Learning English in the current class & 4.6600 & 5.2301 \\
\hline 3 & $\begin{array}{l}\text { Teacher setting realistic and achievable goals for improving } \\
\text { speaking skill }\end{array}$ & 4.5000 & 5.1681 \\
\hline 4 & Teacher making all efforts to achieve these goals & 4.3400 & 5.0531 \\
\hline 5 & Learning how to speak in English in the class & 4.5200 & 5.1593 \\
\hline
\end{tabular}




\begin{tabular}{|c|c|c|c|}
\hline 6 & Teacher giving activities to improve speaking skill & 4.4800 & 5.4690 \\
\hline 7 & Teacher motivating to speak in English & 4.9800 & 5.4956 \\
\hline 8 & $\begin{array}{l}\text { Does your teacher tell you the prospects and benefits of English } \\
\text { language learning }\end{array}$ & 4.4800 & 5.3363 \\
\hline 9 & Does this motivation help you in learning how to speak in English? & 4.9200 & 5.2212 \\
\hline 10 & $\begin{array}{l}\text { Does your teacher keep high expectations from the students as far as } \\
\text { speaking in English is concerned? }\end{array}$ & 4.4200 & 4.8584 \\
\hline 11 & Does your teacher give you the confidence to speak in English? & 5.0800 & 5.4602 \\
\hline 12 & $\begin{array}{l}\text { Does your teacher try to make English learning activities } \\
\text { interesting? }\end{array}$ & 3.6400 & 4.4867 \\
\hline 13 & $\begin{array}{l}\text { Does your teacher set specific activities for learning English for } \\
\text { communicative purposes? }\end{array}$ & 4.3800 & 5.5487 \\
\hline 14 & $\begin{array}{l}\text { Do you find these activities helpful for learning English for } \\
\text { communicative purposes? }\end{array}$ & 3.6000 & 4.2389 \\
\hline 15 & $\begin{array}{l}\text { Does your teacher establish the relevance of the materials to } \\
\text { ordinary life? }\end{array}$ & 4.6400 & 4.9558 \\
\hline 16 & $\begin{array}{l}\text { Does your teacher appreciate you when you perform well in the } \\
\text { class? }\end{array}$ & 5.5000 & 5.8850 \\
\hline 17 & $\begin{array}{l}\text { Does the appreciation of your teacher motivate you to show better } \\
\text { performance? }\end{array}$ & 5.4200 & 5.8053 \\
\hline 18 & Does your teacher get angry when you don't perform well? & 3.8600 & 3.8230 \\
\hline 19 & $\begin{array}{l}\text { Is your teacher careful in avoiding embarrassment while giving you } \\
\text { feedback }\end{array}$ & 4.2600 & 4.7611 \\
\hline 20 & Do you feel free to express yourself in your class? & 3.9800 & 4.2035 \\
\hline 21 & $\begin{array}{l}\text { Does your teacher ask for your opinion about English language } \\
\text { teaching activities in the class? }\end{array}$ & 3.5600 & 4.6814 \\
\hline 22 & Does your teacher remain friendly with you in the class? & 3.8200 & 4.1062 \\
\hline 23 & $\begin{array}{l}\text { Does your teacher resort to social chat to engage you in discussion } \\
\text { in the English language? }\end{array}$ & 4.8200 & 5.5133 \\
\hline
\end{tabular}

The results of the study revealed that the learners' perception towards their teachers' motivational behaviour has although not found to be negative on the majority of the items; however, they restrained to show their strong satisfaction on almost all of the items. The male learners have surpassed or got closer to the level of satisfaction 5 on the majority of the items but remained below the higher or the highest level of satisfaction; however, the female learners restricted their selection on the level below the marker of satisfaction 5 on items No.2,3,4,5,6,8,9,10,13,14,15,16,19,21,22,23. They also expressed their dissatisfaction over the communicative activities carried out by their teachers in the classes believing them to be boring as shown on item No.13. Item No.2 reveals the same fact, which shows that the female learners do not fully enjoy learning English in the classes by restricting their opinion to 4.6 and restrained to surpass the level of satisfaction 5. They also believe that the activities for communication purpose introduced by their teachers are less helpful in improving their oral communication skill (Item No15). They also expressed their dissatisfaction over the current teaching of English believing it less satisfactory and hardly brought about any improvement in their speaking skill (Item No.5). It shows that the female learners seemed little satisfied with their teachers' motivated behaviour that results in negative impact over their attitude towards classroom communicative activities, teachers, courses, and classroom environment etc. This negative attitude restrains learners to get motivated towards engaging in communicative activities actively and to communicate in English with each other in the class to achieve the targeted goals set for getting command over oral communication skill.

The male learners have although surpassed the satisfactory marker 5 on 7 Likert scale on the majority of the items; however, they restrained to show a higher degree of satisfaction on all of the items. On items 
$10,14,16,21,22,23,24,25$ and 27, their mean score remained below the satisfactory level 5 . The learners' perception regarding their teachers' expectations is though not strongly positive even then the learners believe they try to meet their teachers' expectations (Item 10,11). Teachers' expectations were gauged from their efforts in engaging the learners in tasks that lead learners attaining communicative competence in the English language. The male learners seem less satisfied with the nature of the communicative activities carried in the language classroom for their being less interesting and less helpful for learning to communicate in English language, which implies that the learners' attitude towards these activities is not very positive, and they are less motivated to engage in these communicative activities actively (Items 14, 16). Though the learners are satisfied with the cool nature of their teachers but are not happy with their unfriendly behaviour towards them. The learners feel satisfied with the way feedback is given to them by their teachers; however, they also complain that the teachers remain less careful in avoiding embarrassment when giving feedback. It is, therefore, observed that learners do not feel confident to express themselves in the English language not only with teachers but also with their classfellows (Items 20, 24). The learners also restricted themselves to moderate satisfaction on teachers' making the material relevant to the actual context of the outer world, which is one of the main reasons of lack of motivation to improve their oral communication skill.

\section{Discussion and Conclusion}

The overall aim of this study was to investigate whether there were gender differences concerning students' perceptions of the classroom setting controlled by the teacher. As discussed in the literature review, the female learners are more motivated towards language learners and their expectations from their teachers have been recorded in different studies on higher rate compared to the male fellows.

The present study has confirmed that the female learners compared to male ones have gained less score on almost all of the items, and there has been a significant difference between the two genders on the majority of items. It shows that female learners have higher expectations from their teachers so that language learning could further be facilitated. It is therefore concluded that comparatively, the female learners are significantly less satisfied with their teachers' motivating behaviour than their male fellows.

The results point out that teacher can play a significant role in enhancing learners' motivation and building a positive attitude towards language learning. The awareness of gender differences can help to increase their motivational levels. In this regard, the differences in less satisfaction in female gender could be attributed to the attention paid by the teacher to the male gender. As mentioned above, if boys are more prone to seek attention, it may result in undermining girls in a language classroom and they may feel inhibited. Other than teachers' attention, teachers' praise and criticism require just distribution. The tendency to praise boys more n correct responses and less appreciation of girls may be curtailed (Golombok \& Fivush, 1994; Delamont, 1996). This may result in inculcating a feeling where boys seem more confident and girls may feel dissatisfaction at teachers' response.

The study advocates a more reflective approach towards teaching where gender differences should be kept in mind and not undermined especially in second language learning situations. The gender differences may vary in different situations but such kind of studies may be useful for English language teachers to positively use their mentoring skills to facilitate better learning environments for both the genders. Further studies in the domain are encouraged to validate the findings and gain greater insights into English language learning classrooms.

\section{References}

Ahåt, R. (2013). Motivation, gender, and learner performance of English as an L3 in the Xinjiang Uyghur Autonomous Region. English Language Teaching, 6 (9), 158-167.

Ali, A., Ghani, M., Malik, F., \& Ahmad, A. (2016). The Use of Language Learning Strategies by Pakistani MA English Students in Literature/Linguistics, Dialogue, 11(3), 325. 
Ali, M. S., \& Pathan, Z. H. (2017). Exploring factors causing demotivation and motivation in learning English language among college students of Quetta, Pakistan. International Journal of English Linguistics, 7(2), 81-89.

Brophy, J. (1987). Synthesis of Research on Strategies for Motivating Students to Learn, Educational Leadership, 45(2), 40-48.

Deci, E. L., \& Ryan, R. M. (2000). The" what" and" why" of goal pursuits: Human needs and the selfdetermination of behaviour, Psychological Inquiry, 11(4), 227-268.

Delamont, S. (1996). Women's place in education. Brookfield, MA: Avebury Publishers.

Dornyei, Z. (1994). Motivation and motivating in the foreign language classroom, The modern language journal, 78(3), 273-284.

Dornyei, Z. (2001). Teaching and researching motivation, London: Longman.

Dörnyei, Z. (2005). The Psychology of the Language Learner. London: Lawrence Erlbaum Associates.

Dornyei, Z. \& Csizer, K. (1998). Ten commandments for motivating language learners: Results

of an empirical study, Language Teaching Research, 2(3), 203-229

Dornyei, Z., \& Ushioda, E. (2011). Teaching and researching motivation (2nd ed.).

London: Longman.

Dweck, C. S., \& Gilliard, D. Expectancy statements as determinants of reactions to failure: Sex

differences in persistence and expectancy change. Journal of Personality and Social Psychology,

1975, 32, 1077-1084.

Ericksen, S. C. (1978). The Lecture. Memo to the Faculty, no. 60. Ann Arbor: Center for

Research on Teaching and Learning, University of Michigan.

Espelage, D. \& Swearer, S. (2004). Bullying in American schools: A socio-ecological

perspective on prevention and intervention. Mahwah, NJ: Erlbaum.

Ghenghesh, P. (2010). The Motivation of L2 Learners: Does It Decrease with Age?. English

Language Teaching, 3(1), 128-141.

Golombok, S. \& Fivush, R. (1994). Gender development. New York: Cambridge University

Press.

Gömleksiz, M. N. (2001). The effects of age and motivation factors on second language

acquisition. Firat University Journal of social science, 11(2), 217-224.

Kerlinger, F. N. (1986). Foundations of behavioural research (3rd ed.). New York: Holt, Rinehart \& Winston.

Kissau, S.P. (2006). Gender differences in motivation to learn French. Canadian Modern Language

Review, 62 (3), 401-422.

Kormos, J., \& Csizér, K. (2008). Age-related differences in the motivation of learning English

as a foreign language: Attitudes, selves, and motivated learning behaviour. Language learning, 58(2), 327355.

Maccoby, E. (2002). Gender and social exchange: A developmental perspective. San

Francisco: Jossey-Bass.

Mansoor, A. (2016). Motivations and attitudes towards learning English in Pakistan: A mixed-

methods study of urban-rural postgraduate learners' motivations and attitudes towards studying English at a public university in the Khyber Pakhtunkhwa province. (Doctoral dissertation, University of Glasgow).

Maslow, A. H., Frager, R., \& Fadiman, J. (1970). Motivation and personality(Vol. 2, pp.

1887-

1904). New York: Harper \& Row.

McDonough, Jo and Christopher Shaw (2003) 2nd ed. Materials and Methods in EL T.

Blackwell Publishing Ltd.

McElhinny, B. (1993). We all wear the blue: language gender and police work. Unpublished

PhD Thesis, Stanford University. Stanford, CA: USA.

Moyles, J., Hargreaves, L., \& Merry, R. (2003). Interactive teaching in the primary school: Digging deeper into meanings. McGraw-Hill Education (UK).

Murphy, P. K., \& Alexander, P. A. (2000). A motivated look at motivational terminology.

[Special Issue]. Contemporary Educational Psychology, 25, 3-53. 
Nawab, A. (2012). Is it the way to teach language the way we teach language? English language teaching in rural Pakistan. Academic Research International, 2(2), 696.

Noels, K. A., Clément, R., \& Pelletier, L. G. (1999). Perceptions of teachers' communicative style and students' intrinsic and extrinsic motivation. The Modern Language Journal, 83(1), 23-34.

Nunan, D. (1995). Closing the gap between learning and instruction. TESOL Quarterly, 29(1), 133-157.

Öztürk, G. \& Gürbüz, N. (2013). The impact of gender on foreign language speaking anxiety and motivation. Procedia - Social and Behavioral Sciences, 70, 654-665.

Pathan, H. (2012). A longitudinal investigation of Pakistani university students' motivation for learning English (Doctoral dissertation, University of Glasgow).

Pintrich, P. R. (2000). An Achievement Goal Theory Perspective on Issues in Motivation

Terminology, Theory, and Research Contemporary Educational Psychology. 25:

92-104. Retrieved from DOI: 10.1006/ceps.1999.1017

Ruyffelaert, A., \& Hadermann, P. (2012). The impact of age and gender on the learners' motivation and attitudes towards French in secondary education in Flanders. In 6th International Technology, Education and Development Conference (INTED 2012) (pp. 159-165). International Association for Technology, Education and Development (IATED).

Ryan, R. M., \& Deci, E. L. (2000). Intrinsic and extrinsic motivations: Classic definitions and new directions, Contemporary educational psychology, 25(1), 54-67.

Wadho, S., Memon, S., \&Memon, R. A. (2016). Motivation to Learn English language:

Survey on Parents'\& Teachers' Influence on L2 learners in Sindh, Pakistan. Advances in Language and Literary Studies, 7(4), 253-258.

Williams, M., \& Burden, R.L. (1997). Psychology for language teachers. Cambridge: Cambridge University Press.

Wright, T. (1987). Roles for teachers and learners. Oxford: Oxford University Press. 